a right to higher education. With a high enough grade, the student is free to study any subject of his or her choice. But the ever-increasing number of qualified school-leavers has warped this freedom; the student is now also free to fight for a seat in an overcrowded lecture theatre; to wait for years for a place on a popular course; and to spend so many years preparing for final examinations that he or she is barely competitive in the European job market. Gone is the right to expect any sort of personal guidance from teaching staff.

On the other side of the lectern, academics have a constitutional right to freedom. In too many cases this has become synonymous with the right to shelter from accountability. Universities even secure the right of professors to undertake research by giving basic financial support without evaluating the quality of work.

Earlier this year, the Wissenschaftsrat, Germany's influential science advisory body, put forward its list of 'ten propositions' to try to solve the problems. What German higher education needs, it decided, is a system of evaluation of teaching and research in universities, with more power to restrict the finances of those who are not up to scratch. But it also stressed that the answer to overcrowding is not to restrict entry to universities but to expand other forms of higher education, such as the Fachhochschulen (technical colleges).

Reforms are the business of the Länder, but they are restricted to some extent by a federal framework law. This law, for example, prevents universities from introducing temporary faculty posts. There is pressure from many quarters to change this law and give more power to universities. Chancellor Helmut Kohl has recently agreed to discuss such a change this autumn.

But much can be done in the meantime. NordrheinWestfalen reformed its university laws last month. At least two other old Länder - are planning to follow. The proposed changes aim to improve conditions for students by, for example, encouraging a shortening of study times, assessing teaching and providing more staff (and more study places) at the Fachhochschulen. The proposals are relatively gentle, and have been introduced with assurances that fundamental rights will be respected.

Meyer has no such sensibilities. He is a determined man with a vision, who - from a different perspective - looks like a stubborn man on a mission. He has no fear of shocking his new colleagues in the west, many of whom in fact admire him. He has a strong vision for education which contains an element of élitism out of step with modern Germany. His measures (see page 563) are both strict and unforgiving. Performance will be monitored and appropriate action taken. Courses will have the right to restrict student numbers, a concept new in most disciplines where freedom to study is the ruling principle. Students who do not finish their courses in reasonable time will be 'sent down'.

Meyer has shown himself to be brutally uncompromising when dealing with professors accused of having had connections with the Stasi (the secret police), refusing to accept court decisions proving them innocent in his mission to 'democratize' the universities in Saxony (see Nature 363,387; 1993). This iron will, part obsessively democratic, part mercilessly and unreasonably stubborn, may in the long run be exactly what universities in the new Länder need. It may even be what the universities in the old Länder need. Time will tell if his reforms will cure the ills of German universities, whether their implementation will be rigorous enough to cause a backlash, or whether Meyer's growing influence will succeed in rehabilitating the concept of élite universities in Germany.

\section{Fidia fall-out}

\section{Problems at an Italian pharmaceutical company leave Washington's Georgetown University in the lurch.}

FALL-OUT from the implosion of Italy's old, peculiar ways of mixing politics and business will no doubt land in many unlikely places. This summer the aftershock has reached the leafy campus of Georgetown University, Washington DC, where the medical centre can hardly be surprised to see a partnership it forged with troubled Italian pharmaceutical company Fidia come unstuck.

Georgetown is half way through the construction of a 190,000 square foot research building, half of which was supposed to house the Fidia-Georgetown Institute for the Neurosciences, which already operates from other premises at Georgetown. Now the university finds that Fidia is in receivership in Italy, and cannot pay the $\$ 30$ million it promised to pay towards the building's costs. Georgetown - more in hope than expectation, one suspects - has filed a suit to recover the money in the US District Court.

The $\$ 30$ million which Georgetown was scheduled to get from Fidia over fifteen years from 1995 is unlikely to materialize. The university can count itself fortunate that -unlike many institutes of higher education in the US, never mind elsewhere - its finances are strong enough to absorb a hole of this size. Although the Fidia-Georgetown Institute is unlikely to survive in any shape or form, a spokesperson said that it in any case only accounted for 10 per cent of the fast-expanding neuroscience research activity at Georgetown.

It has already been suggested that Georgetown should have smelt a rat: many eyebrows were raised at the extraordinary largesse of Fidia in its heyday. But its assistance to Georgetown was not the sort of thing that many institutions of higher education are likely these days to turn down.

Tough luck, then, for Georgetown. But the real questions that arise from this chain of events are raised back in Italy, where the interesting interface of science and alleged corruption awaits further exploration. Fidia's "success" was borne of the approval by the authorities there of a multipurpose ganglioside, Cronassial. Approval for the drug was never sought in the US, but it was granted in Germany - and withdrawn there in 1989 when patients succumbed to sideeffects. Doubts eventually spread to Italy, but the drug was only withdrawn there - temporarily - earlier this year. Compounding other management problems, that was pretty well the end of the road for Fidia. But for those who have questioned the propriety of the drug approval system in Italy, it is only the beginning. 